OPEN ACCESS

Edited by:

Francesca Chiodi,

Karolinska Institutet (KI), Sweden

Reviewed by:

Vijayakumar Velu,

Emory University, United States

Lucia Lopalco,

San Raffaele Hospital (IRCCS), Italy

*Correspondence:

Marcelo De Carvalho Bittencourt marcelo.decarvalho@univ-lorraine.fr

${ }^{\dagger}$ These authors have contributed equally to this work

Specialty section:

This article was submitted to

Viral Immunology,

a section of the journal

Frontiers in Immunology

Received: 05 July 2020 Accepted: 02 October 2020 Published: 23 October 2020

Citation:

Payen D, Cravat M, Maadadi $H$, Didelot C, Prosic L, Dupuis C, Losser M-R and De Carvalho Bittencourt M (2020) A Longitudinal

Study of Immune Cells in Severe COVID-19 Patients.

Front. Immunol. 11:580250. doi: 10.3389/fimmu.2020.580250

\section{A Longitudinal Study of Immune Cells in Severe COVID-19 Patients}

\author{
Didier Payen ${ }^{1}$, Maxime Cravat ${ }^{2}$, Hadil Maadadi ${ }^{3}$, Carole Didelot ${ }^{4}$, Lydia Prosic ${ }^{4}$, \\ Claire Dupuis ${ }^{5}$, Marie-Reine Losser ${ }^{3,6 \dagger}$ and Marcelo De Carvalho Bittencourt ${ }^{2,4,7 * t}$ \\ 1 Université Paris 7 Denis Diderot, UMR 1160 INSERM, Paris, France, 2 Université de Lorraine, CHRU-Nancy, Laboratoire \\ d'Immunologie, Nancy, France, ${ }^{3}$ Université de Lorraine, CHRU-Nancy, Département d'Anesthésie Réanimation Brabois \\ Adulte, Nancy, France, ${ }^{4}$ CHRU-Nancy, Plateforme de Cytométrie en Flux Diagnostique, Nancy, France, ${ }^{5}$ Service de \\ Médecine Intensive et Réanimation, CHU de Clermont-Ferrand, Clermont-Ferrand, France, ${ }^{6}$ Université de Lorraine, INSERM \\ UMR 1116, Nancy, France, ${ }^{7}$ Université de Lorraine, CNRS UMR 7365, IMoPA, Nancy, France
}

Little is known about the time-dependent immune responses in severe COVID-19. Data of 15 consecutive patients were sequentially recorded from intensive care unit admission. Lymphocyte subsets and total monocyte and subsets counts were monitored as well as the expression of HLA-DR. For 5 patients, SARS-CoV-2-specific T-cell polyfunctionality was assessed against Spike and Nucleoprotein SARS-CoV-2 peptides. Non-specific inflammation markers were increased in all patients. Median monocyte HLA-DR expression was below the 8,000 AB/C threshold defining acquired immunodepression. A "V" trend curve for lymphopenia, monocyte numbers, and HLA-DR expression was observed with a nadir between days 11 and 14 after symptoms' onset. Intermediate CD1 $4^{++} \mathrm{CD} 16^{+}$monocytes increased early with a reduction in classic CD14 ${ }^{++} \mathrm{CD} 16^{-}$ monocytes. Polyfunctional SARS-Cov-2-specific CD4 T-cells were present and functional, whereas virus-specific CD8 T-cells were less frequent and not efficient. We report a temporal variation of both innate and adaptive immunity in severe COVID-19 patients, helpful in guiding therapeutic decisions (e.g. anti-inflammatory vs. immunostimulatory ones). We describe a defect in virus-specific CD8 T-cells, a potential biomarker of clinical severity. These combined data also provide helpful knowledge for vaccine design.

Clinical Trial Registration: https://clinicaltrials.gov/, identifier NCT04386395

Keywords: SARS-CoV-2, immunity, monocyte HLA-DR, antigen-specific polyfunctional T-cells, intensive care unit

\section{INTRODUCTION}

The SARS-CoV-2 outbreak causes a spectrum of clinical patterns that vary from asymptomatic but potentially contagious infection to mildly symptomatic and severe forms (1), suggesting a major role of the host response to SARS-Cov 2 virus. The severe form brings the patient to Intensive Care Units (ICU), with severe hypoxia frequently requiring mechanical ventilation (2). Until now, little is known about the relation between clinical patterns, systemic non-specific markers of inflammation and immune response. The previously reported modifications in severe forms of COVID-19 showed 
increased levels of C-reactive Protein [CRP], ferritin, lactate dehydrogenase $[\mathrm{LDH}]$ ), associated with a marked lymphopenia of CD4 and CD8 T-cell subsets $(3,4)$. Innate immunity investigation reported normal absolute numbers of monocytes, with a reduced expression in their HLA-DR expression (5). Taken together, these modifications suggest an acquired immune-suppression, as reported in bacterial sepsis (6). Elevated levels of pro-inflammatory cytokines, mainly IL-6, have led to the hypothesis of an innate-mediated "cytokine storm" driving a systemic inflammation, neutrophilia and defective antigen-presentation (5). These dysregulations of both innate and adaptive immunity (7) explain apparent contradictions in COVID-19 therapeutic trials (8). We hypothesized that measurements performed only at the ICU admission do not represent the entire clinical picture, since the inflammatory process is varying along time for both innate and adaptive immunity. Consequently, we believe that a longitudinal monitoring may help to understand the complex immune reactions facing severe SARS-Cov2 infection, and be specially useful before decisions on immune-modulation therapeutics and establishing clinically relevant immune-monitoring (9).

This monocentric prospective study of severe ICU COVID patients reports a longitudinal evaluation of innate immunity based on monocyte subsets proportions and expression of HLADR $(7,10)$ and of adaptive immunity based on lymphocyte subsets absolute numbers (AN) and functions, referring to the onset of symptoms. Notably, we report on the presence of peripheral TH1-type SARS-CoV-2-specific T-cells in ICU COVID patients.

\section{METHODS}

\section{Patients}

Among the enormous wave of severe cases admitted from March 30 to April 30, 2020 in east part of France, 15 cases of confirmed COVID-19 (positive RT-PCR for SARS-CoV-2 and suggestive chest CT-Scan) were prospectively investigated after ICU admission at the University Hospital of Nancy (CHRUNancy), France. The protocol was approved by the Innovation and Research Direction (reference 2020PI080), and by the Research Ethical Committee (Saisine 263) of CHRU-Nancy and registered at nih.gov (NCT04386395). No additional samples were drawn and no cells or plasma were stored after completion of the study. Relatives or patients themselves were questioned about objections to use the collected data for scientific purposes and/or potential publications. These statements and the non-opposition forms were dated and recorded in medical files.

After medical team consensus, patients did receive neither direct/indirect anti-viral treatment nor immunomodulating drugs except for 3 patients who received low dose steroids, allowing results interpretation based on a relatively pure COVID-19 natural evolution. Medical history, delay from the onset of symptoms and ICU admission (Table S1), classic clinical and routine biological data were recorded.

\section{Study Design}

Complete blood cell evaluation was categorized according to time intervals from both the onset of symptoms and ICU admission for blood sampling as follows (Figure S1): A: days (d) $7-10$ as a $1^{\text {st }}$ period (48 hours after ICU admission); B from d11 to 14; C from d15 to 18 ; D from d19 to 23 ; E: after d24. Similar analyses were performed referring to the delay from ICU admission: A: d0-4; B: d5-8; C: d9-12; D: late > d12 (Table S2). Also, in order to achieve a sufficient number of cases to test the relation between non-specific markers of inflammation with immune cellular response, the patients were alternatively grouped as follows: 1 : days 7 to 14,2 : days 15 to 23, and 3: after day 24 (Table 3).

\section{Laboratory Investigations}

Routine parameters, nonspecific inflammatory markers and immune-cells characterization were first measured on ICU admission (Tables $\mathbf{1}$ and 2 ) and these values were considered as baseline. Serial measurements were repeated until the patient was discharged or died. Flow-cytometry whole-blood routine analyses of circulating monocytes and lymphocytes were performed at the Diagnostic Flow-Cytometry platform of CHRU Nancy by using the BD FACSLyric ${ }^{\mathrm{TM}}$ Clinical System (BD Biosciences, San Jose, CA). All fluorochrome-conjugated antibodies and reagents were from BD Biosciences.

\section{Innate Immunity}

Whole-blood monocytes were selected as previously reported (Figure S2) (11). CD14-positive (+) cells with intermediate SSC were analyzed. Because of their specialized functions and phenotypes $(10,12)$, monocyte subsets were further analyzed based on CD14 and CD16 expression as classical (CD14 $\left.{ }^{++} \mathrm{CD} 16^{-}\right)$, non-classical $\left(\mathrm{CD} 14^{\text {low }} \mathrm{CD} 16^{++}\right)$, and intermediate $\left(\mathrm{CD} 14^{++} \mathrm{CD} 16^{+}\right)$ (13). Relative and absolute populations sizes were determined and HLA-DR expression was quantified as number per cell (antibodies bound per cell $[\mathrm{AB} / \mathrm{C}]$ arbitrary units) using a commercial kit (Quantibrite $^{\mathrm{TM}}$, BD Biosciences). Total monocytes HLA-DR median expression in healthy donors, using similar set-up conditions, was $16,884(5,842-29,175) \mathrm{AB} / \mathrm{C}$. Our laboratory's threshold for acquired immunodepression diagnosis is $8,000 \mathrm{AB} / \mathrm{C}$ $(11,14)$. "Normal proportions" for monocyte subsets are $80 \%$ to $95 \%$ for classical monocytes, $2 \%$ to $8 \%$ for non-classical monocytes and $2 \%$ to $11 \%$ for intermediate monocytes $(12,13)$.

\section{Adaptive Immunity}

Routine whole-blood immunophenotyping of T, B and NK lymphocytes by flow-cytometry determined relative and $\mathrm{AN}$ of lymphocytes and their subsets, i.e. $\mathrm{CD}^{+} \mathrm{T}$-cells, $\mathrm{CD} 3^{+} \mathrm{CD} 4^{+} \mathrm{T}$ cells, $\mathrm{CD}^{+} \mathrm{CD}^{+}{ }^{+}$-cells, CD $19^{+}$B-cells, CD3 ${ }^{-} \mathrm{CD} 16^{+} 56^{+} \mathrm{NK}-$ cells. Regulatory T-cells (Treg) were identified in whole blood as $\mathrm{CD} 3{ }^{+} \mathrm{CD} 4{ }^{+} \mathrm{CD} 25^{++} \mathrm{CD} 127^{\text {neg/low }}$ cells $(15,16)$. SARS-CoV-2specific $\mathrm{T}$-cell polyfunctionality $(17,18)$ against viral peptides was assessed in 5 patients to further explore COVID-19 adaptive immunity (patients \#7, \#9, \#11, \#12, and \#13). Patients' PBMC from 19 to 29 days after the onset of symptoms were stimulated ex-vivo by overlapping peptides covering protein sequences of the Spike and Nucleoprotein SARS-CoV-2 antigens (JPT Peptide 
Technologies, Berlin, Germany). Antigen-specific T-cells reactivity was assessed by intracellular IFN- $\kappa$, TNF- $\alpha$ and IL- 2 production (19). Navios ${ }^{\circledR}$ flow-cytometer and Kaluza ${ }^{\circledR}$ software v2.1 (Beckman Coulter, Miami, FL) were used for data acquisition and analysis. As positive controls, PBMC were also stimulated by a mix of immunodominant microbial peptides (CEFX peptide pool; JPT Peptide Technologies) for diverse microbial antigens-specific TH1 responses. Antigen-specific CD4 and CD8 T-cells polyfunctionality was expressed by using the "Polyfunctionality Index" (PI) $(18,20)$. More details in reagents, flow-cytometry gating strategy used for the selection and quantification of Sars-Cov-2-specific T-cells are shown in Table S3 and Figure S3.

\section{Statistical Analyses}

Data were described as number (\%) and median (interquartile range (IQR)) for categorical and continuous variables, respectively. Linearity of the variables were assessed via qqplot and Shapiro-Wilk tests. HLA was $\log 10$ transformed afterwards. To take into account the small samples sizes, comparisons relied on Fisher exact test for categorical data and Kruskal-Wallis or Wilcoxon tests for continuous data. Wilcoxon for paired tests were used to determine pair-wise differences. For the repeated measurements, summary statistics such as differences and median were initially used. Then, to assess and compare the variability of the variables over time, mixed-effects models were used. A p-value of less than 0.05 was considered significant. All analyses were performed using SAS software, version 9.4 (SAS) and $\mathrm{R}$ software, version 3.6.3.

\section{RESULTS}

\section{Cohort of Consecutive Patients}

Forty six measurements in 15 severe COVID-19 ICU patients were performed. The median age was 66 years old [60-72], 80\% male, with median BMI of 29 [24.5; 32] and hypertension in $46.7 \%$ (Table 1). The severity score were 49 [42; 65] for SAPS 2, 7 $[4 ; 8]$ for SOFA (neuro component excluded), and SOFA resp $_{\text {at }} 3$ [3; 4] (Table 1). Comorbidities were present in $47 \%$ of the patients with pre-existent cancer (33.3\%) and diabetes $(26.7 \%)$ (Table 1). Because of hypoxia deterioration, all except 1 (Table S1) needed intubation and mechanical ventilation with a protective lung ventilation protocol. Importantly, none of the patients received any direct or indirect antiviral drugs nor specific immunomodulating drugs. Only 3 patients received low dose of prednisolone during their ICU stay (Table 1). Three patients died (20\%) during the $2^{\text {nd }}$ or $3^{\text {rd }}$ week after ICU admission. All other patients were ICU discharged. A ventilatoracquired pneumonia according to classical CDC definition (21) was diagnosed in $26.7 \%$ of the patients.

\section{Laboratory Findings}

Non-specific markers of systemic inflammation such as CRP, ferritin, DDimers, fibrinogen, $\mathrm{LDH}$, and the complement fraction C4 were largely above normal ranges in $100 \%$ of the
TABLE 1 | Clinical characteristics, comorbidities, severity scores, nonspecific markers, metabolic parameters at the time of enrollment.

\begin{tabular}{|c|c|c|}
\hline Variable & Value & $\begin{array}{l}\text { Normal } \\
\text { range }\end{array}$ \\
\hline Number of patients & 15 & \\
\hline \multicolumn{3}{|l|}{ Patients' characteristics } \\
\hline Age (y.o.) & $66[60 ; 72] /(54 \mid 75)$ & \\
\hline Gender (male) & $12(80)$ & \\
\hline $\mathrm{BMl}\left(\mathrm{kg} / \mathrm{m}^{2}\right)$ & $29[24.5 ; 32] /(22 \mid 43)$ & \\
\hline \multicolumn{3}{|l|}{ Comorbidities } \\
\hline Diabetes & $4(26.7)$ & \\
\hline Hypertension & $7(46.7)$ & \\
\hline Obesity & $6(40)$ & \\
\hline $\mathrm{BMl}$ & $1(6.7)$ & \\
\hline COPD & $2(13.3)$ & \\
\hline Asthma & $1(6.7)$ & \\
\hline SAS & $2(13.3)$ & \\
\hline Smoker & $2(13.3)$ & \\
\hline Cancer & 5 (33.3) & \\
\hline \multicolumn{3}{|l|}{ On admission } \\
\hline Delay 1st Symptoms & $9[7 ; 14] /(1 \mid 18)$ & \\
\hline SAPS2 & $49[42 ; 65] /(22 \mid 80)$ & \\
\hline SOFA & $7[4 ; 8] /(4 \mid 12)$ & \\
\hline SOFA resp & $3[3 ; 4] /(0 \mid 4)$ & \\
\hline Corticosteroids & $3(20)$ & \\
\hline \multicolumn{3}{|l|}{$\begin{array}{l}\text { Nonspecific markers of } \\
\text { inflammation }\end{array}$} \\
\hline $\mathrm{PCT}$ (miss=2) & $0.9[0.5 ; 3.1] /(0.1 \mid 37)$ & \\
\hline $\mathrm{CRP}(\mathrm{miss}=1) \mathrm{mg} / \mathrm{ml}$ & $174.4[134 ; 284] /(85 \mid 389.2)$ & $0 ; 0-10.0$ \\
\hline $\mathrm{LDH}$ & $439.5[397 ; 525] /(388 \mid 885)$ & $120-246$ \\
\hline Ferritin (miss=3) $(\mu \mathrm{g} / \mathrm{l})$ & $\begin{array}{l}888.5[451 ; 2385] /(348 \mid \\
7200)\end{array}$ & $22-322$ \\
\hline Ddimers (miss $=1)(\mu \mathrm{g} / \mathrm{l})$ & $\begin{array}{l}1742[1599 ; 3220] /(804 \mid \\
10000)\end{array}$ & $45-500$ \\
\hline Fibrinogen (miss=2) $(\mathrm{g} / \mathrm{l})$ & $7.8[6.5 ; 8.2] /(4.3 \mid 9.9)$ & $1.7-4$ \\
\hline C3 (miss=7) (g/l) & $1.6[1.4 ; 1.8] /(1.2 \mid 2.4)$ & $0.9-1.7$ \\
\hline C4 (miss=7) (g/l) & $0.4[0.3 ; 0.4] /(0.3 \mid 0.5)$ & $0.12-0.36$ \\
\hline \multicolumn{3}{|l|}{ Metabolic parameters } \\
\hline Albuminemia (miss=1) $(\mathrm{g} / \mathrm{l})$ & $25.5[23.1 ; 27.4] /(18.2 \mid 31.5)$ & $35-52$ \\
\hline Cholesterol (miss=8) $(\mathrm{g} / \mathrm{l})$ & $3.2[2.5 ; 4] /(1.8 \mid 4)$ & $<2$ \\
\hline $\mathrm{TG}(\mathrm{miss}=4)(\mathrm{g} / \mathrm{l})$ & $2.1[1.3 ; 2.4] /(1.1 \mid 2.8)$ & $<1.5$ \\
\hline Glycemia (g/l) & $1.5[1.2 ; 1.8] /(0.9 \mid 3.3)$ & $<1.2$ \\
\hline Lactate (mM/l) & $1.3[1 ; 1.5] /(0.8 \mid 1.6)$ & $<2$ \\
\hline \multicolumn{3}{|l|}{ Outcomes } \\
\hline VAP & $4(26.7)$ & \\
\hline Delay before VAP (miss=11) & $13.5[7 ; 15.5] /(1 \mid 17)$ & \\
\hline ICU LOS & $12[10 ; 23] /(5 \mid 30)$ & \\
\hline Death & $3(20)$ & \\
\hline
\end{tabular}

Data are expressed as medians [Interquartile IQ] or percentages (\%). SAPS2: simplified acute physiological score; SOFA, sequential organ failure assessment; VAP, ventilatory acquired pneumonia; COPD, chronic obstructive pulmonary disease; SAS, sleep apnea syndrome; PCT, procalcitonin; $L D H$, Lactate dehydrogenase; CRP, C-reactive protein; C3, C4, complement fractions; TG, triglycerides.

patients at ICU admission (Table 1). DDimers levels were 3 times above the highest normal limit. Glycemia was slightly superior to normal values $(1.5[1.2 ; 1.8] \mathrm{g} / \mathrm{L})$, with normal lactate levels $(1.3[1 ; 1.5] \mathrm{mM} / \mathrm{L})$. Surprisingly, cholesterol $(3.2[2.5 ; 4] \mathrm{g} / \mathrm{L})$ and triglycerides $(2.1[1.3 ; 2.4] \mathrm{g} / \mathrm{L})$ levels were also largely above normal ranges, a lipid abnormality never reported in severe septic patients (22). Absolut numbers (AN) and relative values of leukocyte subsets are shown in Table 2 and Figure 1. Considering the delay stratification from symptoms onset, there was globally no significant change in leukocyte AN $(p=0.09)$. 
Polymorphonuclears (PMN) initial AN were lower than the median observed at the later phases $\mathrm{D}(\mathrm{p}=0.04)$ and $\mathrm{E}(\mathrm{p}=$ 0.06) (Table 2 and Figure 1). A difference in monocyte AN was only significant when phase B (d11-14) was compared to the late phase E ( $p=0.04)$ (Table 2 and Figure 1). Importantly, the proportion of monocytes CD16+ intermediate was largely over the normal values (Table 2) $(10,23)$. Over time, the relative number for the 3 major subtypes of monocytes did not change significantly (Table 3). The ability of monocytes to express HLADR was lower than the threshold for acquired immunosuppression diagnosis at all periods, except for the latest measurement ( $>24$ days after initial symptoms) (Figure 2). The lowest level of immunosuppression was observed at the initial phase $\mathrm{d} 7-14$ and tended to recover at the phase d15-D23 and d24-35, 14 days after

TABLE 2 | Time intervals of absolute and relative values referring to the onset of symptoms for blood lymphocytes, monocytes, polymorphonuclear cells and human leucocyte antigens-DR (HLA-DR, expressed in AB/C number of events per cell).

\begin{tabular}{|c|c|c|c|c|c|c|c|c|c|c|c|c|c|}
\hline Variable & A : days 7-10 & $\begin{array}{c}\text { B : days } \\
11-14\end{array}$ & C : days 15-J18 & D : days 19-23 & $E$ : days > 24 & $\begin{array}{l}\text { Normal } \\
\text { range }\end{array}$ & Miss & $\begin{array}{l}P^{*} \\
\text { All }\end{array}$ & $\begin{array}{l}P^{* *} \\
A-B\end{array}$ & $\begin{array}{l}P^{\star \star} \\
A-D\end{array}$ & $\begin{array}{l}P^{\star \star} \\
A-E\end{array}$ & $\begin{array}{l}P^{* \star} \\
B-D\end{array}$ & $\begin{array}{l}P^{* *} \\
B-E\end{array}$ \\
\hline $\begin{array}{l}\text { Number of } \\
\text { patients }\end{array}$ & 5 & 9 & 12 & 11 & 9 & & & & & & & & \\
\hline $\begin{array}{l}\text { Leukocytes } \\
(109 / /)\end{array}$ & $\begin{array}{c}8.12 \text { [7.83; } \\
11.61]\end{array}$ & $\begin{array}{c}10.79 \text { [9.68; } \\
11.23]\end{array}$ & $\begin{array}{c}10.3[6.8 \\
13.79]\end{array}$ & $\begin{array}{c}11.48 \text { [10.6; } \\
15.19]\end{array}$ & $\begin{array}{c}13.5[11.7 \\
14.7]\end{array}$ & $4.0-10.0$ & 5 & 0.09 & & & 0.04 & & 0.04 \\
\hline PMNs (109/l) & $\begin{array}{c}6.26[5.88 \\
7.09]\end{array}$ & $\begin{array}{c}8.59 \text { [7.79; } \\
9.34]\end{array}$ & $\begin{array}{c}6.12[4.64 \\
9.07]\end{array}$ & $\begin{array}{c}9.06 \text { [8.03; } \\
11.26]\end{array}$ & $9.5[7.6 ; 11]$ & $1.5-7.0$ & 11 & 0.08 & & 0.04 & 0.06 & & \\
\hline $\begin{array}{l}\text { Monocytes } \\
(109 / /)\end{array}$ & $\begin{array}{c}0.55[0.34 \\
0.96]\end{array}$ & $\begin{array}{c}0.52[0.35 \\
0.6]\end{array}$ & $\begin{array}{c}0.67[0.27 \\
0.84]\end{array}$ & $0.61[0.52 ; 0.79]$ & $0.9[0.7 ; 1]$ & $0.2-1.0$ & 3 & & & & & & 0.04 \\
\hline $\begin{array}{l}\text { Monocytes } \\
\text { CD16- (\%) }\end{array}$ & $\begin{array}{c}28.41[21.26 \\
54.56]\end{array}$ & $\begin{array}{c}69.72[42.19 \\
\quad 83.76]\end{array}$ & $\begin{array}{c}59.51[41.16 \\
75.64]\end{array}$ & $\begin{array}{c}53.26 \text { [19.73; } \\
66.88]\end{array}$ & $\begin{array}{c}56.6[44.1 \\
68.3]\end{array}$ & $80-85$ & 7 & & & & & & \\
\hline $\begin{array}{l}\text { Monocytes Int } \\
\text { (\%) }\end{array}$ & $\begin{array}{c}67.51[39.18 \\
72.95]\end{array}$ & $\begin{array}{c}27.95[14.57 ; \\
48.09]\end{array}$ & $\begin{array}{c}37.81[19.77 \\
53.92]\end{array}$ & $\begin{array}{c}43.18[30.11 ; \\
67.24]\end{array}$ & 35.9 [29.3; 53] & $2-11$ & 7 & & & & & & \\
\hline $\begin{array}{l}\text { Monocytes } \\
\text { CD16+ (\%) }\end{array}$ & $\begin{array}{c}3.04[2.49 \\
5.3]\end{array}$ & $\begin{array}{c}1.49 \text { [1.06; } \\
7.5]\end{array}$ & $\begin{array}{c}2.52 \text { [1.96; } \\
3.77]\end{array}$ & $\begin{array}{c}3.96[1.62 ; \\
10.23]\end{array}$ & $3.7[1.2 ; 7.7]$ & $2-8$ & 7 & & & & & & \\
\hline $\mathrm{HLA}(\mathrm{AB} / \mathrm{C})$ & $\begin{array}{c}6396 \text { [3360; } \\
6479]\end{array}$ & $\begin{array}{c}3237 \text { [2853; } \\
4173]\end{array}$ & $\begin{array}{c}4850 \text { [4033.5; } \\
7193]\end{array}$ & $\begin{array}{c}5094 \text { [4170; } \\
7895]\end{array}$ & $\begin{array}{c}8406 \text { [3466.5; } \\
11776]\end{array}$ & $\begin{array}{l}16884 \\
{[5842-} \\
29175]\end{array}$ & 1 & & & & & 0.08 & 0.08 \\
\hline $\begin{array}{l}\text { HLA CD16- } \\
(\mathrm{AB} / \mathrm{C})\end{array}$ & $\begin{array}{c}4199 \text { [2467; } \\
6680]\end{array}$ & $\begin{array}{c}2769[1897 ; \\
4400]\end{array}$ & $\begin{array}{c}3422.5 \text { [2762.5; } \\
5499.5]\end{array}$ & $\begin{array}{c}4009.5[2278.5 \\
6088]\end{array}$ & $\begin{array}{c}4922.5[2515 ; \\
6899]\end{array}$ & & 7 & & & & & & \\
\hline $\begin{array}{l}\text { HLA Int (AB/ } \\
\text { C) }\end{array}$ & $\begin{array}{c}8805 \text { [3684; } \\
9510]\end{array}$ & $\begin{array}{c}4758.5 \\
{[3457.5 ;} \\
9677]\end{array}$ & $\begin{array}{c}7907.5[4984.5 \\
12331.5]\end{array}$ & $\begin{array}{c}7883 \text { [4416; } \\
12552]\end{array}$ & $\begin{array}{c}9623.5 \text { [5756; } \\
20052]\end{array}$ & & 7 & & & & & & \\
\hline $\begin{array}{l}\text { HLA CD16+ } \\
(\mathrm{AB} / \mathrm{C})\end{array}$ & $\begin{array}{c}34565 \\
{[16673 ;} \\
48542]\end{array}$ & $\begin{array}{c}11864 \text { [5352; } \\
30733]\end{array}$ & $\begin{array}{c}24179.5 \\
{[12204 ; 33577]}\end{array}$ & $\begin{array}{c}29197.5[24749 \\
42757.5]\end{array}$ & $\begin{array}{c}39806.5 \\
{[16598 ; 71223]}\end{array}$ & & 7 & & & & & 0.09 & 0.08 \\
\hline Lymphocytes & $\begin{array}{c}1.28[1.18 ; \\
2.05]\end{array}$ & $\begin{array}{c}0.54[0.45 \\
0.91]\end{array}$ & $\begin{array}{c}0.86[0.63 \\
1.71]\end{array}$ & $1.07[0.96 ; 1.44]$ & $1.8[1 ; 2]$ & $1.0-3.0$ & 2 & 0.03 & 0.07 & & & 0.03 & 0.02 \\
\hline LT4 (109/l) & $\begin{array}{c}0.64[0.57 \\
0.66]\end{array}$ & $\begin{array}{l}0.26[0.2 \\
0.44]\end{array}$ & $\begin{array}{c}0.46[0.34 \\
0.68]\end{array}$ & 0.57 [0.45; 0.65] & $0.8[0.4 ; 1.1]$ & $0.55-1.5$ & 2 & 0.06 & 0.07 & & & 0.03 & 0.06 \\
\hline LT4 (\%) & $\begin{array}{c}50 \text { [27.8; } \\
\quad 56.3]\end{array}$ & $\begin{array}{c}54.45[42.65 \\
57.25]\end{array}$ & $\begin{array}{c}48.7 \text { [41.6; } \\
62.05]\end{array}$ & $47.9[42.5 ; 53]$ & $\begin{array}{c}48.3[45.3 ; \\
51.8]\end{array}$ & & 2 & & & & & & \\
\hline LT8 (109/l) & $\begin{array}{c}0.15[0.11 ; \\
0.94]\end{array}$ & $\begin{array}{c}0.07 \text { [0.03; } \\
0.1]\end{array}$ & $\begin{array}{c}0.12 \text { [0.04; } \\
0.28]\end{array}$ & 0.19 [0.09; 0.2] & $0.3[0.1 ; 0.4]$ & $0.3-1.3$ & 2 & 0.02 & 0.08 & & & 0.02 & $<.01$ \\
\hline LT8 (\%) & $11.8[9.7 ; 46]$ & $\begin{array}{c}9.8[6.1 \\
14.45]\end{array}$ & $\begin{array}{c}14.85[8.4 \\
16.1]\end{array}$ & $13.6[8.8 ; 20]$ & $\begin{array}{c}16.2[14.4 ; \\
19.2]\end{array}$ & & 2 & & & & & & 0.03 \\
\hline LB (109/l) & $\begin{array}{c}0.32[0.21 ; \\
0.33]\end{array}$ & $\begin{array}{c}0.14[0.1 \\
0.21]\end{array}$ & $\begin{array}{c}0.15[0.06 \\
0.56]\end{array}$ & $0.21[0.14 ; 0.25]$ & $0.4[0.2 ; 0.5]$ & $0.09-0.6$ & 2 & & & & & & 0.05 \\
\hline LB (\%) & $\begin{array}{c}17.8 \text { [16.3; } \\
20.4]\end{array}$ & $\begin{array}{c}22.5[19.85 \\
25.95]\end{array}$ & $20.1[8.5 ; 33.1]$ & 14.6 [11.1; 28.8] & $\begin{array}{c}20.9 \text { [16.3; } \\
26.3]\end{array}$ & & 2 & & & & & & \\
\hline L NK (109/l) & $\begin{array}{c}0.11[0.11 \\
0.15]\end{array}$ & $\begin{array}{c}0.09[0.04 \\
0.14]\end{array}$ & $0.1[0.05 ; 0.14]$ & $0.15[0.09 ; 0.23]$ & $0.1[0.1 ; 0.2]$ & $0.15-1.1$ & 2 & & & & & & \\
\hline L NK (\%) & $8[5.3 ; 8.2]$ & $\begin{array}{c}11.1[8.35 ; \\
18.6]\end{array}$ & $\begin{array}{c}11.8[6.25 \\
14.5]\end{array}$ & $14.5[7.6 ; 17]$ & $7.7[4.5 ; 10]$ & & 2 & & & 0.09 & & & 0.10 \\
\hline CD4/CD8 & $\begin{array}{c}4.05[0.62 ; \\
5.6]\end{array}$ & $\begin{array}{c}5.26 \text { [2.89; } \\
8.57]\end{array}$ & $3.83[2.5 ; 5.32]$ & 2.78 [2.52; 5.02] & $2.8[2.4 ; 3.3]$ & & 2 & & & & & & 0.10 \\
\hline Treg (109/l) & $6.1[5 ; 8.3]$ & $\begin{array}{c}7.85[6.9 \\
10.15]\end{array}$ & $7.5[6.5 ; 10.55]$ & $9.15[6 ; 14.9]$ & $8.3[6.5 ; 9.7]$ & & 3 & & & & & & 0.88 \\
\hline $\begin{array}{l}\text { PMNs/ } \\
\text { Lymphocytes }\end{array}$ & $\begin{array}{c}5.13[2.72 ; \\
5.35]\end{array}$ & $\begin{array}{c}15.88[6.37 ; \\
19.06]\end{array}$ & $\begin{array}{c}5.46[2.91 \\
10.74]\end{array}$ & $\begin{array}{c}6.85[5.72 ; \\
11.13]\end{array}$ & $7.3[3.4 ; 9]$ & & 13 & 0.05 & 0.02 & 0.06 & & & 016 \\
\hline
\end{tabular}

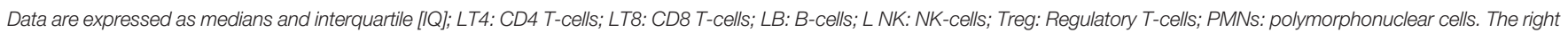

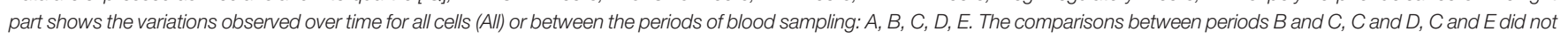
show any significance. ${ }^{*} p$-value: Kruskall-Wallis test; ${ }^{* *} p$-value: Wilcoxon test. 

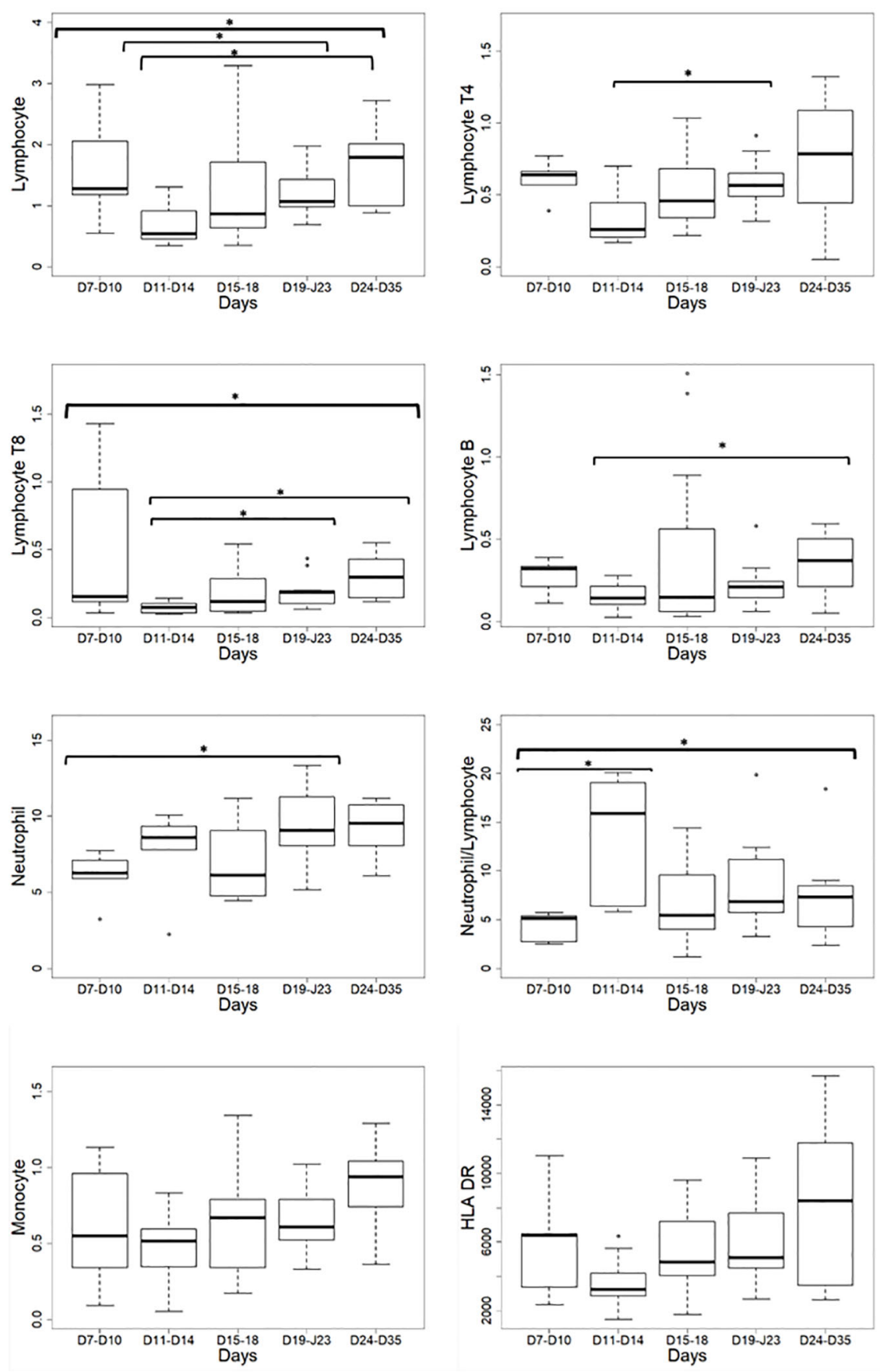

FIGURE 1 | Leukocyte absolute number variations according to the delay from the onset of symptoms. HLA-DR: Human Leucocyte Antigen-DR expressed as events per cell $(\mathrm{AB} / \mathrm{C}) ;{ }^{*} \mathrm{p}<0.05$.

symptoms, with an increase in proportion of CD16+ monocytes $(\mathrm{p}<0.01)$ (Figure 2). Similar patterns were observed for all monocyte subtypes, albeit more pronounced for $\mathrm{CD} 16^{+}$ monocytes (non-classical and intermediate) (Table 3). The association between modifications in monocyte proportions and HLA-DR expression and the nonspecific inflammatory markers is summarized in Table 4. No associations were found between the proportions of monocyte subtypes and the initial level (low or high value referring to the median) of CRP, DDimers, LDH and Ferritin (Table 4). For CRP, CD16+ intermediate monocytes increased the HLA-DR expression when the initial level was lower than the median value $(\mathrm{p}<0.02)$. Similarly when DDimers level was considered, both CD16+ and CD16+ intermediate monocytes increased their HLA-DR expression along time $(\mathrm{p}<0.04)$ when 
TABLE 3 | Longitudinal cellular immune-inflammatory response referring to the delay from initial symptoms.

\begin{tabular}{|c|c|c|c|c|c|}
\hline & A: Day 7 - 14 & B: Day 15-23 & C: Day 24-35 & p-val All* & $p$-val $A \mid B^{\star *}$ \\
\hline Number of patients & 8 & 12 & 7 & & \\
\hline Leukocytes $\left(10^{9} / \mathrm{l}\right)$ & $10.8[9.7 ; 12.2]$ & $11.7[8.9 ; 14.7]$ & 14.4 [12.9; 14.8] & 0.08 & - \\
\hline PMNs $\left(10^{9} /\right)$ & $7.9[7.7 ; 9.2]$ & $9[6.3 ; 11.3]$ & $10[8.5 ; 11]$ & - & - \\
\hline Lymphocytes $\left(10^{9} / \mathrm{l}\right)$ & $0.6[0.4 ; 1.2]$ & $0.9[0.6 ; 1.5]$ & $1.4[1 ; 1.9]$ & 0.03 & - \\
\hline $\operatorname{LB}\left(10^{9} /\right)$ & $0.1[0.1 ; 0.3]$ & $0.2[0.1 ; 0.2]$ & $0.3[0.2 ; 0.4]$ & - & - \\
\hline $\operatorname{LT4}\left(10^{9} / \mathrm{l}\right)$ & $0.3[0.2 ; 0.6]$ & $0.5[0.3 ; 0.7]$ & $0.6[0.4 ; 1]$ & 0.09 & - \\
\hline LT8 $\left(10^{9} /\right)$ & $0.1[0 ; 0.1]$ & $0.1[0.1 ; 0.3]$ & $0.2[0.1 ; 0.3]$ & - & - \\
\hline CD4/CD8 & $4.1[1.6 ; 8.2]$ & $2.8[2.2 ; 5]$ & $2.6[2.4 ; 2.9]$ & - & - \\
\hline L NK $\left(10^{9} / \mathrm{l}\right)$ & $0.1[0 ; 0.2]$ & $0.2[0.1 ; 0.2]$ & $0.1[0.1 ; 0.2]$ & - & 0.06 \\
\hline Treg $\left(10^{9} / /\right)$ & $8.3[5 ; 10]$ & $7.1[5.7 ; 9.5]$ & $8.3[6.2 ; 10.3]$ & - & 0.06 \\
\hline PMN/Lymphocytes & $10.8[5.8 ; 19.1]$ & $7.3[5.2 ; 9.9]$ & $7.6[5.1 ; 9]$ & - & - \\
\hline Monocytes $\left(10^{9} / \mathrm{l}\right)$ & $0.6[0.4 ; 0.8]$ & $0.7[0.5 ; 0.9]$ & $1[0.7 ; 1.1]$ & 0.09 & - \\
\hline Monocytes CD16- (\%) & $59.4[42.4 ; 85.9]$ & $64.3[43.3 ; 73.2]$ & $48.6[44.1 ; 64.5]$ & - & - \\
\hline Monocytes Int (\%) & $38.3[14.6 ; 73]$ & 53.9 [34.8; 62.2] & $42.1[29.8 ; 53]$ & - & - \\
\hline Monocytes CD16+ (\%) & $1.6[1 ; 9.9]$ & $4.1[2.6 ; 9.5]$ & $5.9[1.5 ; 7.7]$ & - & 0.06 \\
\hline $\log H L A(A B / C)$ & $8.1[7.9 ; 8.5]$ & $8.5[8.1 ; 8.7]$ & $8.6[8 ; 9.2]$ & - & - \\
\hline Log HLA CD16- (AB/C) & $8[7.5 ; 8.3]$ & $8.1[7.6 ; 8.5]$ & $8.5[7.8 ; 8.5]$ & - & - \\
\hline Log HLA Int (AB/C) & $8.6[8.1 ; 9.2]$ & $8.7[8.2 ; 9.3]$ & $9[8.7 ; 9.3]$ & - & - \\
\hline Log HLA CD16+ (AB/C) & $9[8.5 ; 10.4]$ & $10[9.3 ; 10.3]$ & $10.2[9.7 ; 11.2]$ & 0.1 & - \\
\hline
\end{tabular}

Data are expressed as medians [Interquartile IQ] or percentages (\%). PMNs: Polymorphonuclears; L : Lymphocytes; Log: Log $10 .{ }^{*}$ mixed-effects models; **Wilcoxon paired t test.

the DDimers level was lower than the median. Ferritin levels were also associated with the time dependent increase in HLA-DR expression in CD16- monocytes $(\mathrm{p}<0.03)$ and CD16+ monocytes $(p<0.04)$. LDH levels were not associated with the changes in HLA-DR expression. No relation was found between the initial values of the nonspecific inflammatory markers and the lymphocytes subsets.

A significant positive correlation was found at all periods between HLA-DR expression and T-cells AN for CD4 $\left(\mathrm{R}^{2}=0.28\right.$; $\mathrm{p}<0.01)$ and CD8 T-cells $\left(\mathrm{R}^{2}=0.22 ; \mathrm{p}<0.01\right)$ (not shown). Also, significant linear positive correlations were seen between HLADR expression on intermediate and non-classic monocyte subsets and CD4 T-cells AN $(\mathrm{p}<0.01)$ and between $\mathrm{CD} 16^{+}$ intermediate subset and CD8 T-cells AN ( $\mathrm{p}<0.01)$ (not shown). The analysis of the 3 patients who died did not suggest any specific patterns related to the poor prognosis, when compared to the surviving patients.

As reported (24), global lymphocyte counts showed a severe reduction in AN compared to normal ranges (Table 2 and Figure 1). Lymphocyte AN changed significantly over time ( $p=0.03$ ). CD4 (“B” vs "D": $p=0.03$ ) and CD8 ("B" vs "D": $\mathrm{p}=0.02) \mathrm{T}$-cell AN were reduced at period $\mathrm{B}$, being the "nadir" of lymphopenia, and then followed by a slow CD4 and CD8 Tcells increase $(\mathrm{p}<0.03)$ (Figure 1). The CD4/CD8 ratio was not impacted by lymphopenia. B-cells, NK-cells, and Treg numbers were stable along the monitoring time (Table 2). The leukocyte moderate elevation associated with the total lymphocytes rapid decline resulted in a significant rise in PMNs/Lymphocytes ratio at the "nadir" period B, with subsequent normalization (Table 2).

\section{Functional Analysis of Cellular Immune Response in SARS-CoV-2 Patients}

Peripheral SARS-CoV-2-specific T-cells were identified in 5 patients by using an intracellular staining assay and flowcytometry to evaluate the production of 3 TH1 cytokines contributive to viral clearance (17). PBMC were stimulated by 3 SARS-CoV-2 peptide pools (Sk1 and Sk2 pools and Nucleoprotein (NC pool)). The polyfunctionality Index (PI) for IFN- $\gamma$, TNF- $\alpha$ and IL-2 production showed that virusspecific CD4 T-cells were more polyfunctional than CD8 T-cells (Figure 3). Remarkably, a high proportion of bifunctional and tri-functional CD4 T-cells was observed, whereas CD8 T-cells were essentially monofunctional (Figure 3). Nucleoprotein-specific CD4 T-cells were less numerous than those specific for the Spike glycoprotein (both Sk1 and Sk2 pools), similarly to reported results (25). CD4 $\mathrm{T}$-cells responses to immunodominant peptides from different infectious agents (CEFX pool) were much lower than CD8 T-cells responses (Figure 4).

\section{DISCUSSION}

The most significant predictors of disease severity in COVID-19 infection relate to both innate and adaptive immunity and their inter-relations. Until now, to our knowledge, no longitudinal clinical study on ICU-admitted patients has reported the evolution of monocyte subsets with concomitant HLA-DR expression and lymphocytes subsets AN. Precise knowledge of symptoms' onset allowed us to interpret the collected data as related to disease progression, instead of admission time to ICU. Between symptoms' onset and ICU admission to ICU discharge or death, we observed a "V" curve trend for monocytes and their HLA-DR expression as well as for lymphopenia, with a nadir between days 11 to 14 . This 2 weeks timing already reported as a risk period for clinical events (1) was characterized by the lowest HLA-DR expression on monocyte subsets associated with the deepest CD4 and CD8 T-cells lymphopenia. The early intensity of inflammation characterized by the blood nonspecific markers levels seems to relate with the amplitude of immune modifications in monocyte subsets and their HLA-DR expression, concomitant 


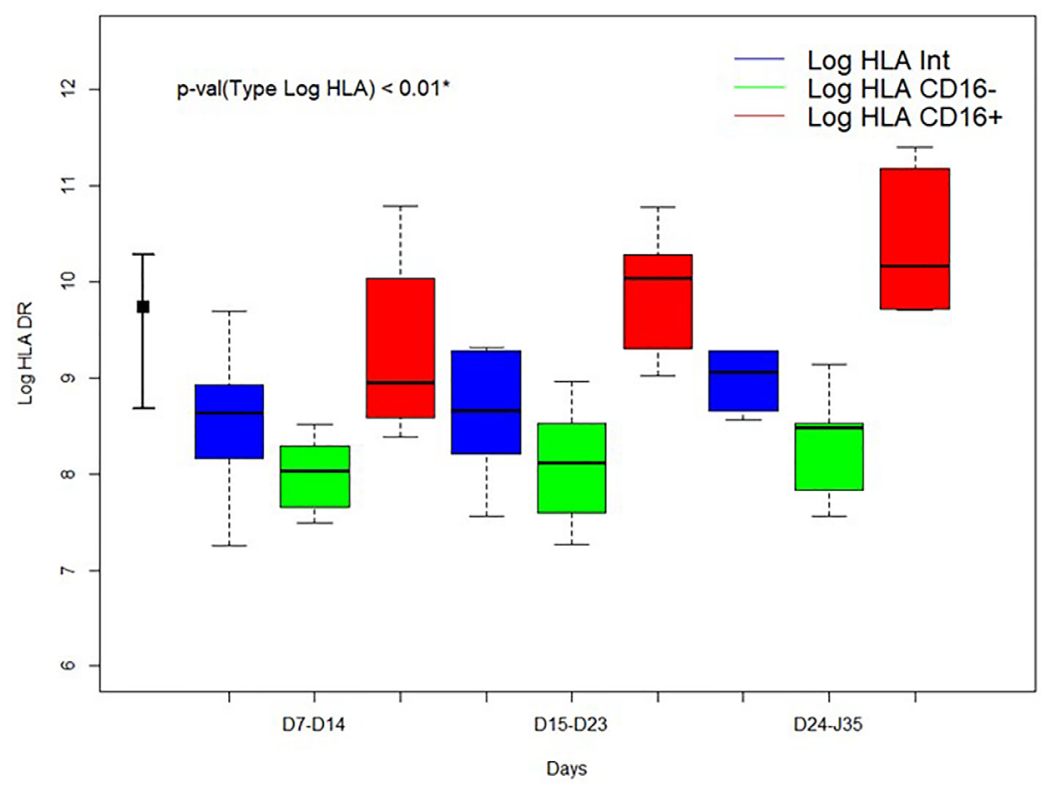

FIGURE 2 | Time evolution of HLA-DR expression according to the delay from the onset of symptoms for 3 monocyte subtypes. Blue: intermediate $\left(\right.$ CD14 ${ }^{++}$CD16 ${ }^{+}$) monocytes; green: classical (CD14 ${ }^{++}$CD16 $)$monocytes; red: non-classical (CD14 ${ }^{+}$CD16 $\left.{ }^{++}\right)$monocytes. HLA-DR: Human Leucocyte Antigen-DR expressed as events per cell (AB/C). *Kruskall-Wallis test comparing the median values of HLA-DR expression of monocytes subtypes during all stay. Log: Log 10 . At left normal expected values for HLA-DR expression in total monocytes.

with lymphopenia. The more these nonspecific inflammatory markers were initially elevated, the slower was the recovery of monocytes HLA-DR expression after the nadir 2 weeks post symptoms, an effect not yet reported in COVID 19 nor in septic patients. In this respect, the level of ferritin appeared the most promising marker with the addition of DDimers. Concerning the adaptative antigen-specific immunity, we found in a subset of patients that mainly polyfunctional SARS-Cov-2-specific CD4 Tcells were present 3 weeks after the onset of symptoms, while peripheral SARS-Cov-2-specific CD8 T-cells were less numerous and not efficient. However, a normal CD8 T-cells response for other microbial antigens was present, excluding a global functional defect of peripheral CD8 T-cells in these patients.

This ICU cohort had a predominance of males with high Body Mass Index and frequent comorbidities, as previously reported (26). Acute respiratory syndrome with severe hypoxia imposed intubation and mechanical ventilation for 14/15 patients. However, our cohort differs from others by several aspects: no patient received any anti-viral therapy or specific immunomodulatory drugs before and during ICU stay, avoiding a potential incidence on the immune profile. At referral to ICU, all patients had elevated levels of non-specific markers of systemic inflammation such as ferritin, LDH, and CRP. The mortality rate $(20 \%)$ was relatively low and none of the patients experienced shock nor multiorgan failure. The reasons for that are not clear, except the reduced interference between drugs and immune status.

In absence of a longitudinal assessment, one-point checking for immune status has big limitations. As shown here, both innate and adaptive immunity vary over time after SARS-CoV-2 infection. COVID-19 severity is related to an initial excessive inflammatory response, pro-inflammatory cytokine storm and global lymphopenia as well as pulmonary mononuclear cell infiltration (27). The reported monocyte and macrophage hyperactivation have a major role on this hyperinflammatory state, potentially depending on their interaction with virus-specific T-cells $(5,28,29)$. The virus itself, directly via pathogen-associated molecular patterns and indirectly via damage-associated molecular patterns, may activate multiple immune pathways (7).

If monocytes can initiate and amplify adaptative immune responses, they also play a key role supporting tissue homeostasis by resolving these responses to avoid excessive tissue damage (10). Monocyte classical $\left(\mathrm{CD} 14^{++} \mathrm{CD} 16^{-}\right)$, non-classical $\left(\mathrm{CD} 14^{+} \mathrm{CD} 16^{++}\right)$and intermediate $\left(\mathrm{CD} 14^{++} \mathrm{CD} 16^{+}\right)$subsets reflect different functions $(10,23)$. Only one study has reported monocyte subsets proportions in 3 ICU COVID-19 patients (30). In our study, monocyte AN did not change along with COVID evolution in ICU, except when comparing the last measurements (>24 days) with those of days 11 to 14 after symptoms onset. Previous reports also showed maintained monocyte numbers (28). Proportions of the 3 monocyte subsets did not change significantly during the evolution period we studied. However, the intermediate $\mathrm{CD} 14^{++} \mathrm{CD} 16^{+}$subset was remarkably always above reported normal values $(10,23)$, which was associated with reduced proportions of classic $\mathrm{CD} 14^{++} \mathrm{CD} 16^{-}$monocytes, as reported (30). Functionally, HLA-DR global expression was below the $8,000 \mathrm{AB} / \mathrm{C}$ threshold defining acquired immunosuppression $(11,14)$, with similar trends for the 3 subsets. Such changes in 
TABLE 4 | Association of monocytes sub-populations and HLA-DR expression with nonspecific inflammatory parameters.

\begin{tabular}{|c|c|c|c|c|c|c|c|c|c|c|c|c|c|c|}
\hline & Period & miss & Low CRP & High CRP & $\mathbf{p}^{*}$ & $\begin{array}{c}\text { Low } \\
\text { Ddimers }\end{array}$ & $\begin{array}{c}\text { High } \\
\text { Ddimers }\end{array}$ & $\mathbf{p}^{*}$ & Low LDH & High LDH & $\mathbf{p}^{*}$ & $\begin{array}{c}\text { Low } \\
\text { ferritin }\end{array}$ & $\begin{array}{l}\text { High } \\
\text { Ferritin }\end{array}$ & $\mathbf{p}^{*}$ \\
\hline \multirow[t]{4}{*}{$\begin{array}{l}\text { Monocytes CD } \\
16-(\%)\end{array}$} & A & 2 & $\begin{array}{c}57.7[32.6 ; \\
84.8]\end{array}$ & $\begin{array}{c}43.3 \text { [42.2; } \\
62.9]\end{array}$ & - & $\begin{array}{c}56.1 \text { [43.3; } \\
84.8]\end{array}$ & $\begin{array}{c}48.5[37.4 \\
61.2]\end{array}$ & - & $0.8[0.6 ; 1]$ & $\begin{array}{c}0.5[0.3 ; \\
0.7]\end{array}$ & - & $0.7[0.6 ; 1]$ & $\begin{array}{c}0.4[0.3 ; \\
0.5]\end{array}$ & - \\
\hline & $B$ & 3 & $\begin{array}{c}74.7 \text { [36.9; } \\
81.8]\end{array}$ & $\begin{array}{c}21.5 \text { [8.8; } \\
42]\end{array}$ & - & $\begin{array}{c}81.3 \text { [31.6; } \\
81.8]\end{array}$ & $\begin{array}{c}36.9[14.6 ; \\
68.1]\end{array}$ & - & $\begin{array}{c}0.8[0.6 ; \\
0.8]\end{array}$ & $\begin{array}{c}0.6[0.6 \\
1.1]\end{array}$ & - & $\begin{array}{c}0.8[0.6 ; \\
1.1]\end{array}$ & $\begin{array}{c}0.6[0.6 ; \\
0.7]\end{array}$ & - \\
\hline & B-A & 3 & $\begin{array}{c}4.4[-3.5 \\
25.7]\end{array}$ & $\begin{array}{c}-24.2 \\
{[-35.5 ;-0.4]}\end{array}$ & - & $\begin{array}{c}-3.2[-3.5 \\
11.9]\end{array}$ & $\begin{array}{c}-14 \\
{[-35.5} \\
7.2]\end{array}$ & - & $\begin{array}{c}0[-0.4 ; \\
0.2]\end{array}$ & $0.2[0 ; 0.2]$ & - & $0.2[0 ; 0.2]$ & $0[0 ; 0.2]$ & - \\
\hline & $B-A>0$ & 3 & $3(50)$ & $1(16.7)$ & - & $2(40)$ & 2 (28.6) & - & $2(50)$ & $7(77.8)$ & - & $6(75)$ & $3(60)$ & - \\
\hline \multirow[t]{4}{*}{$\begin{array}{l}\text { Monocytes CD } \\
16+(\%)\end{array}$} & $A$ & 2 & $\begin{array}{c}1.8[1.2 ; \\
4.4]\end{array}$ & $3.2[1.7 ; 5.3]$ & - & $\begin{array}{c}2.3[1.4 \\
4.7]\end{array}$ & $\begin{array}{c}3.1[1.4 ; \\
4.8]\end{array}$ & - & $\begin{array}{c}84.8 \text { [42.2; } \\
85.9]\end{array}$ & $\begin{array}{c}48.9[32.6 ; \\
59.4]\end{array}$ & - & $\begin{array}{c}54.6[42.2 ; \\
62.9]\end{array}$ & $\begin{array}{c}50.9[31.8 \\
76.7]\end{array}$ & - \\
\hline & $\mathrm{B}$ & 3 & $\begin{array}{c}2.4[1.6 \\
4.1]\end{array}$ & $\begin{array}{c}9.7[2.5 \\
10.6]\end{array}$ & - & $\begin{array}{c}2.5[2.2 ; \\
9.5]\end{array}$ & $\begin{array}{c}4.1[1 ; \\
10.6]\end{array}$ & - & $\begin{array}{c}81.3[6.7 ; \\
82.7]\end{array}$ & $\begin{array}{c}36.9 \text { [28.4; } \\
68.1]\end{array}$ & - & $\begin{array}{c}49.8[11.7 \\
81.6]\end{array}$ & $\begin{array}{c}39.4[32.6 ; \\
61]\end{array}$ & - \\
\hline & B-A & 3 & $\begin{array}{c}-0.1[-0.3 ; \\
0.2]\end{array}$ & $3.7[0.3 ; 5.3]$ & 0.09 & $0.2[0 ; 2.2]$ & $\begin{array}{c}0.3[-0.3 ; \\
5.3]\end{array}$ & - & $\begin{array}{c}-3.5 \\
{[-35.5} \\
-3.2]\end{array}$ & $\begin{array}{c}-0.4 \\
{[-22.5} \\
11.9]\end{array}$ & - & $\begin{array}{c}-3.3[-35 \\
18.8]\end{array}$ & $\begin{array}{c}-7.2 \\
{[-18.2} \\
3.4]\end{array}$ & - \\
\hline & $B-A>0$ & 3 & 2 (33.3) & 5 (83.3) & 0.08 & $3(60)$ & $4(57.1)$ & - & $0(0)$ & $4(44.4)$ & - & $3(37.5)$ & $1(25)$ & - \\
\hline \multirow[t]{4}{*}{$\begin{array}{l}\text { Monocytes Int } \\
\text { (\%) }\end{array}$} & $A$ & 2 & $\begin{array}{c}39.6 \text { [14.6; } \\
62.2]\end{array}$ & $\begin{array}{c}49.6[34.8 ; \\
54]\end{array}$ & - & $\begin{array}{c}40.9 \text { [14.6; } \\
51.3]\end{array}$ & $\begin{array}{c}44.4[36.5 \\
58.1]\end{array}$ & - & $\begin{array}{c}1.4[0.3 ; \\
3.2]\end{array}$ & $\begin{array}{c}3.7[1.7 ; \\
5.3]\end{array}$ & - & $\begin{array}{c}3.2[1.7 \\
4.7]\end{array}$ & $\begin{array}{c}2.1[0.9 ; \\
5.1]\end{array}$ & - \\
\hline & $\mathrm{B}$ & 3 & $\begin{array}{c}21.1[14.9 \\
57.1]\end{array}$ & $\begin{array}{c}70.2 \text { [46.6; } \\
80.5]\end{array}$ & 0.07 & $\begin{array}{c}15 \text { [14.9; } \\
57.1]\end{array}$ & $\begin{array}{c}61.3 \text { [27.3; } \\
73]\end{array}$ & - & $\begin{array}{c}2.5[1.6 ; \\
11]\end{array}$ & $\begin{array}{c}4.1[2.2 ; \\
9.9]\end{array}$ & - & $\begin{array}{c}6.8[2.4 \\
10.6]\end{array}$ & $\begin{array}{c}1.7[0.9 ; \\
6.2]\end{array}$ & - \\
\hline & B-A & 3 & $\begin{array}{c}-3.1 \\
{[-25.9} \\
2.9]\end{array}$ & $20[-3 ; 29.3]$ & - & $\begin{array}{l}0.4[-6.5 \\
\quad 2.9]\end{array}$ & $\begin{array}{c}12.6[-7 ; \\
27.3]\end{array}$ & - & $\begin{array}{c}2.2[0.2 ; \\
7.8]\end{array}$ & $\begin{array}{l}0[-0.3 \\
2.7]\end{array}$ & - & $\begin{array}{c}1.2[-0.1 \\
5.1]\end{array}$ & $\begin{array}{l}0[-0.4 \\
1.5]\end{array}$ & - \\
\hline & $B-A>0$ & 3 & $3(50)$ & $4(66.7)$ & - & $3(60)$ & $4(57.1)$ & - & $3(100)$ & $4(44.4)$ & 0.09 & $5(62.5)$ & $2(50)$ & - \\
\hline \multirow[t]{4}{*}{ Log HLA (AB/C) } & $A$ & 0 & $\begin{array}{c}8.6[8.4 ; \\
9.2]\end{array}$ & $8.4[8.1 ; 8.8]$ & - & $\begin{array}{l}8.5[8.3 ; \\
9.2]\end{array}$ & $\begin{array}{c}8.6[8.1 ; \\
8.8]\end{array}$ & - & $\begin{array}{c}14.6[11.7 ; \\
54]\end{array}$ & $\begin{array}{c}45.2 \text { [38.3; } \\
62.2]\end{array}$ & - & $\begin{array}{c}40.9[34.8 ; \\
54]\end{array}$ & $\begin{array}{c}43.9[21.6 ; \\
62]\end{array}$ & - \\
\hline & $\mathrm{B}$ & 2 & $\begin{array}{l}8.8[8.5 ; \\
8.9]\end{array}$ & 8.3 [7.9; 8.5] & - & $\begin{array}{l}8.8[8.5 ; \\
8.9]\end{array}$ & $\begin{array}{l}8.2[7.8 \\
\quad 8.6]\end{array}$ & - & $\begin{array}{c}15 \text { [14.6; } \\
81.4]\end{array}$ & $\begin{array}{c}57.1[27.3 ; \\
67.5]\end{array}$ & - & $\begin{array}{c}42.2[14.9 \\
76.7]\end{array}$ & $\begin{array}{c}54[32.1 \\
64.4]\end{array}$ & - \\
\hline & B-A & 2 & $\begin{array}{l}0[-0.4 \\
0.3]\end{array}$ & $\begin{array}{c}-0.1[-0.6 \\
0.1]\end{array}$ & - & $\begin{array}{l}0.1[0.1 ; \\
0.3]\end{array}$ & $\begin{array}{c}-0.4[-0.5 \\
-0.1]\end{array}$ & 0.07 & $\begin{array}{c}2.9[0.4 \\
27.3]\end{array}$ & $-3[-7 ; 23]$ & - & $\begin{array}{c}1.7[-16.2 ; \\
28.3]\end{array}$ & $\begin{array}{c}4.8[-5 \\
17.8]\end{array}$ & - \\
\hline & $B-A>0$ & 2 & $3(50)$ & $3(42.9)$ & - & $4(80)$ & $2(25)$ & 0.05 & $3(100)$ & $4(44.4)$ & 0.09 & $5(62.5)$ & $2(50)$ & - \\
\hline \multirow[t]{4}{*}{$\begin{array}{l}\log \text { HLA CD } 16 \\
-(\mathrm{AB} / \mathrm{C})\end{array}$} & A & 2 & $\begin{array}{l}8.4[8.2 ; \\
\quad 8.5]\end{array}$ & $8[7.8 ; 8.9]$ & - & $\begin{array}{c}8.2[8.2 ; \\
8.5]\end{array}$ & $\begin{array}{l}8.1[7.8 ; \\
8.8]\end{array}$ & - & $\begin{array}{l}8.5[8.4 ; \\
8.6]\end{array}$ & $\begin{array}{c}8.6[8.1 ; \\
8.9]\end{array}$ & - & $\begin{array}{c}8.7[8.4 ; \\
9.2]\end{array}$ & $\begin{array}{c}8.1[8.1 ; \\
8.5]\end{array}$ & 0.10 \\
\hline & $\mathrm{B}$ & 3 & $\begin{array}{c}8.5[8.3 ; \\
8.6]\end{array}$ & $7.9[7.5 ; 8]$ & - & $\begin{array}{c}8.6[8.3 ; \\
8.6]\end{array}$ & $\begin{array}{c}7.8[7.3 \\
8.5]\end{array}$ & - & $\begin{array}{l}8.5[8.5 \\
\quad 8.8]\end{array}$ & $\begin{array}{c}8.4[7.9 \\
8.9]\end{array}$ & - & $\begin{array}{c}8.8[8.5 ; \\
8.9]\end{array}$ & $7.8[7.6 ; 8]$ & 0.02 \\
\hline & $B-A$ & 3 & $\begin{array}{l}0.1[-0.2 ; \\
\quad 0.3]\end{array}$ & $\begin{array}{c}-0.1[-0.6 \\
0]\end{array}$ & - & $0.3[0 ; 0.3]$ & $\begin{array}{c}-0.1[-0.6 \\
-0.1]\end{array}$ & - & $\begin{array}{c}0[-0.1 \\
0.4]\end{array}$ & $\begin{array}{c}-0.3[-0.5 \\
0.1]\end{array}$ & - & $\begin{array}{c}0.1[-0.1 \\
0.3]\end{array}$ & $\begin{array}{c}-0.4[-0.6 \\
-0.3]\end{array}$ & 0.08 \\
\hline & $B-A>0$ & 3 & $3(50)$ & $1(16.7)$ & - & $3(60)$ & $1(14.3)$ & 0.10 & $2(66.7)$ & $4(40)$ & - & $6(66.7)$ & $0(0)$ & 0.03 \\
\hline \multirow[t]{4}{*}{$\begin{array}{l}\text { Log HLA CD } 16 \\
+(\mathrm{AB} / \mathrm{C})\end{array}$} & $A$ & 2 & $9.7[9 ; 10]$ & $\begin{array}{c}10.4[10.2 \\
10.6]\end{array}$ & - & $\begin{array}{c}9.7[9.7 ; \\
10]\end{array}$ & $\begin{array}{c}10.3[9.7 \\
10.5]\end{array}$ & - & $8.2[8 ; 8.5]$ & $\begin{array}{c}8.3[7.8 ; \\
8.7]\end{array}$ & - & $\begin{array}{c}8.3 \text { [8.2; } \\
8.5]\end{array}$ & $\begin{array}{c}7.8[7.7 \\
8.4]\end{array}$ & - \\
\hline & $\mathrm{B}$ & 3 & $\begin{array}{c}10.1[10 ; \\
10.3]\end{array}$ & $\begin{array}{c}10.3[9.7 \\
10.6]\end{array}$ & - & $\begin{array}{c}10.3[10.2 ; \\
10.6]\end{array}$ & $\begin{array}{c}10.1[9.1 \\
10.5]\end{array}$ & - & $\begin{array}{c}8.3[7.8 ; \\
8.6]\end{array}$ & 8 [7.5; 8.6] & - & $\begin{array}{c}8.5[8.2 ; \\
8.7]\end{array}$ & $\begin{array}{c}7.4[7.3 \\
7.8]\end{array}$ & 0.04 \\
\hline & B-A & 3 & $\begin{array}{c}0.4[0.1 \\
0.6]\end{array}$ & $0[-0.7 ; 0.1]$ & 0.07 & $\begin{array}{c}0.5[0.3 ; \\
0.6]\end{array}$ & $\begin{array}{c}0[-0.7 \\
0.1]\end{array}$ & 0.04 & $\begin{array}{c}-0.1[-0.2 ; \\
0.4]\end{array}$ & $\begin{array}{c}-0.1[-0.5 \\
0.3]\end{array}$ & - & $\begin{array}{c}0.1[-0.1 \\
0.4]\end{array}$ & $\begin{array}{c}-0.6[-0.7 \\
-0.3]\end{array}$ & 0.04 \\
\hline & $B-A>0$ & 3 & 5 (83.3) & $3(50)$ & - & $5(100)$ & $3(42.9)$ & 0.04 & 1 (33.3) & 3 (33.3) & - & $4(50)$ & $0(0)$ & 0.08 \\
\hline \multirow[t]{4}{*}{$\begin{array}{l}\text { Log HLA Int } \\
(\mathrm{AB} / \mathrm{C})\end{array}$} & $A$ & 2 & $\begin{array}{c}8.9[8.7 ; \\
9.3]\end{array}$ & $8.8[8.2 ; 9.2]$ & - & $8.8[8.7 ; 9]$ & $\begin{array}{c}8.9 \text { [8.3; } \\
9.2]\end{array}$ & - & $\begin{array}{c}9.7[8.4 ; \\
10.2]\end{array}$ & $\begin{array}{c}10.3[9.7 ; \\
10.6]\end{array}$ & - & $\begin{array}{c}10.2[9.7 ; \\
10.6]\end{array}$ & $\begin{array}{c}9.8[9.1 ; \\
10.4]\end{array}$ & \\
\hline & $\mathrm{B}$ & 3 & $\begin{array}{c}9.5 \text { [9.3; } \\
9.9]\end{array}$ & $8.5[8.1 ; 8.6]$ & - & $\begin{array}{c}9.5[9.3 ; \\
9.9]\end{array}$ & $\begin{array}{c}8.5[7.8 ; \\
9.4]\end{array}$ & 0.10 & $\begin{array}{c}10.2[10.2 ; \\
10.3]\end{array}$ & $\begin{array}{c}10.1[9.7 \\
10.6]\end{array}$ & - & $\begin{array}{c}10.2[10.1 \\
10.6]\end{array}$ & $\begin{array}{c}9.4[8.8 \\
10.1]\end{array}$ & 0.10 \\
\hline & $B-A$ & 3 & $\begin{array}{c}0.2[0.2 ; \\
0.8]\end{array}$ & $\begin{array}{c}-0.3[-0.4 \\
-0.1]\end{array}$ & - & $\begin{array}{c}0.2[0.2 ; \\
0.8]\end{array}$ & $\begin{array}{c}-0.3[-0.4 \\
0.2]\end{array}$ & 0.08 & $0.6[0 ; 1.8]$ & $\begin{array}{l}0.1[-0.6 ; \\
\quad 0.2]\end{array}$ & - & $0.2[0 ; 0.6]$ & $\begin{array}{c}-0.3[-0.7 \\
0.1]\end{array}$ & \\
\hline & $B-A>0$ & 3 & 5 (83.3) & $1(16.7)$ & 0.02 & $4(80)$ & $2(28.6)$ & 0.08 & $2(66.7)$ & $6(66.7)$ & - & $6(75)$ & $2(50)$ & \\
\hline
\end{tabular}

Data are expressed as medians [Interquartile IQ] or percentages (\%). Miss: Missing values. Log: Log ${ }_{10}^{*}{ }^{*} p$-value: Fisher exact test and Wilcoxon test as appropriate. Values B-A>0 refer for numbers of patients (\% of total patients) for each monocyte sub-population. No significant results were observed within the lymphocyte subsets.

monocyte proportions and functionality appear related to disease severity and suggest a maturation towards macrophages (28). The severe reduction in HLA-DR expression observed was comparable with that observed in bacterial sepsis (6) or trauma (14). The reported SARS-CoV-2 virus-induced restriction in interferon genes expression may account for severe reduction in different IFN proteins, including IFN-א (29). The close correlation between
CD4 and CD8 T-cells numbers and monocyte HLA-DR expression levels supports such hypothesis. The severe reduction in monocyte HLA-DR expression may also result from other mechanisms such as monocyte dysfunction, particularly secondary to exposure to IL-6 $(5,31)$, which requires further investigation.

COVID-19 mortality has been shown to correlate to global Tcell function as indirectly measured by T-cell lymphopenia (32). 

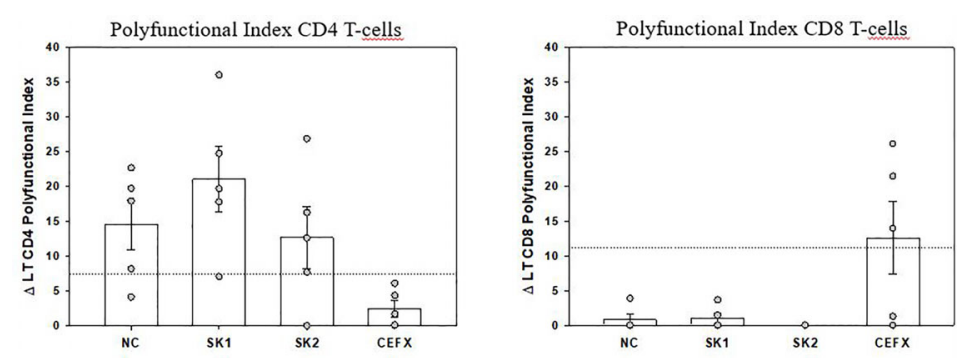

FIGURE 3 | Polyfunctional Index (PI) of SARS-CoV-2-specific CD4 and CD8 T-cells. The PI of antigen-specific CD4 and CD8 T-cells from 5 patients was calculated as previously described $(18,20)$ for each antigen stimulation. Data are expressed after subtraction of "background polyfunctionality" of medium-stimulated cells $(\Delta$ PI). Dotted lines correspond to PI positivity threshold as determined at 3SD of 30 negative controls measures for CD4 and CD8 T-cells. Bars are shown as mean \pm SEM. LT CD4: CD4 T-cells, LT CD8: CD8 T-cells.
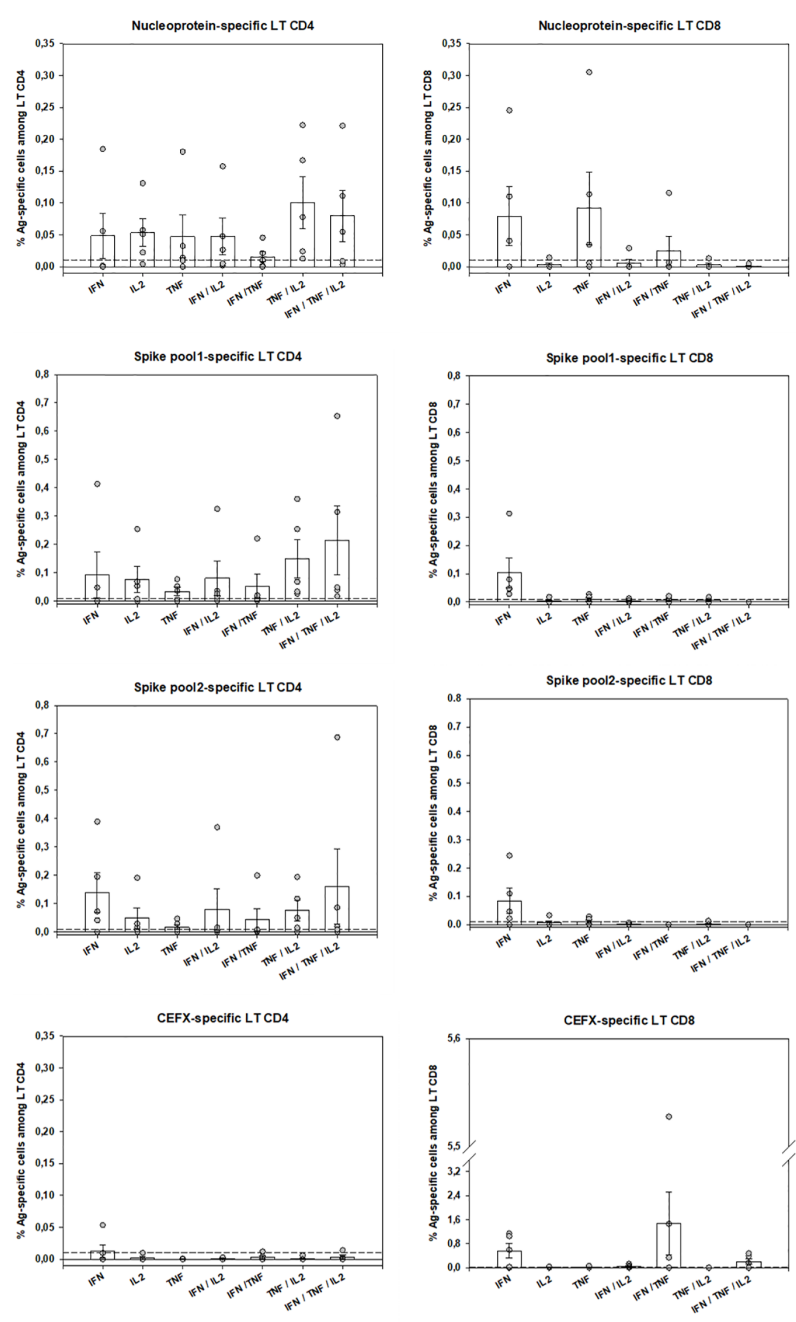

FIGURE 4 | SARS-CoV-2-specific-T-cells numbers and functions. Peripheral antigen-specific CD4 and CD8 T-cells from 5 patients were identified by intracellular staining of IFN- $\kappa$, TNF- $\alpha$ and IL-2 by flow-cytometry as described (see Material and Methods and Suppl. Methods sections). Shown are individual data from stimulation with SARS-CoV-2 Nucleoprotein and Spike Glycoprotein peptides pools as well as by multiple immunodominant microbial peptides (CEFX pool) for CD4 and CD8 T-cells and for each cytokine capability (monofunctional, bifunctional or trifunctional). Basal cytokine production of medium-stimulated cells was subtracted for each antigen-stimulated cell subtype and a $0.01 \%$ positivity threshold was defined (dotted lines). Bars are shown as mean \pm SEM. LT CD4: CD4 T-cells, LT CD8: CD8 T-cells. 
However, the successful containment of viral infections depends on the generation of antigen-specific TH1-polarized CD4 and CD8 T-cells, with a huge increase of effector T-cells at acute phase, which declines after successful virus control, yet maintaining an increased pool of pathogen-specific memory T-cells $(33,34)$. More than the quantity itself, anti-viral "T-cells quality" is widely recognized as the most important for successful anti-viral responses. It relates to the cells' capacity to perform simultaneous anti-viral functions (e.g. cytokine or chemokine production, cytotoxicity, proliferation) $(17,18)$. Indeed, polyfunctional and monofunctional $\mathrm{T}$-cells differ at molecular levels (35). At the time of writing, only 4 publications have assessed SARS-CoV-2-specific T-cells. Ni et al. described them in COVID-19 recovered patients, using only IFN- $\gamma$ ELISpot, possibly underestimating the magnitude and breadth of the response and not discriminating CD4 or CD8 virus-specific T-cells (36). The other 3 studies identified by flow-cytometry T-cells upregulating activation markers $(25,37,38)$. Although this "global activation" approach can potentially detect all antigenspecific T-cells, polyfunctional CD4 T-cells were not investigated. Grifoni et al. described only polyfunctional CD8 T-cells, assessed from recovered patients (38). Therefore, to date no study has assessed both CD4 and CD8 T-cell polyfunctionality in the COVID-19 context, especially on ICU patients. We believe that such evaluation is important to better understand immune responses against this new virus. Of note, in previous SARSCoV epidemics, specific polyfunctional CD4 and CD8 T-cells were present several years after infection (39). The large combinatorial datasets of multiparametric flow-cytometry analysis of polyfunctionality can be integrated in a onedimensional numerical tool, called polyfunctional index (PI) that integrates degrees and variations of cellular polyfunctionality (18, 20). Its application here showed that polyfunctional CD4 T-cells were present for at least one of the SARS-CoV-2 tested antigens in all 5 tested patients. Conversely, CD8 polyfunctional T-cells were not identified for any SARS-CoV-2 antigen in any patient. SARS$\mathrm{CoV}$-specific CD4 T-cells were mainly bi- (mostly TNF- $\alpha+\mathrm{IL}-2+$ ) and tri-functional (plus IFN- $\gamma$ ). Conversely, when present, the rare SARS-CoV-2-specific CD8 -reactive T-cells were mainly monofunctional (producing either IFN- $\gamma$ or TNF- $\alpha$ ). Of note, the CD8 T-cells reactive to the control mix of microbial peptides mentioned above (CEFX pool) were perfectly polyfunctional, indicating again that only the pool of peripheral SARS-CoV-2specific CD8 T-cells is affected (Figures 3 and 4). This difference in quantity and quality between CD4 and CD8 SARS-CoV-2-specific T-cells might be explained by a preferential homing of the virusspecific effector CD8 T-cells to tissues, and especially the lungs and/ or by T-cell functional exhaustion $(40,41)$. The latter hypothesis, that would imply selective PD-1 expression, is not supported by the good specific responses of helper CD4 T-cells in the same samples. Further evaluations of SARS-CoV-2-specific T-cells in bronchoalveolar lavage and of the expression of T-cell exhaustion inhibitory markers (e.g. PD-1 and TIM-3) are then warranted. Virus-specific CD8 T-cells are key in eliminating virus-infected cells (33) and Grifoni et al. have reported their presence in recovered patients (38). Combined with our findings, one may therefore hypothesize that inefficient SARS-CoV-2-specific CD8 $\mathrm{T}$-cell responses could promote viral persistence and then virusinduced inflammatory damage in severe COVID-19 patients. Overall, SARS-CoV-2-specific polyfunctional CD4 T-cells were present at relatively high numbers, by comparison to other antigenspecific T-cells routinely investigated in our laboratory (42), suggesting a strong immune response. Further studies are needed to establish the kinetics of circulating SARS-CoV-2-specific T-cells over time and their relationship with COVID-19 clinical presentation.

In conclusion, we report the first concomitant and longitudinal evaluation of innate and adaptive immunity in COVID-19 severe cases in relation with admission values of blood nonspecific markers of inflammation. We believe that such extensive immunomonitoring studies are needed in order to accumulate a better knowledge in SARS-CoV-2 innate and adaptive immune-responses relationships. This approach might be helpful in making therapeutic decisions (e.g. antiinflammatory $v s$. immunostimulation interventions) depending on the stage of the disease. This also will be of utmost importance for vaccine efficacy evaluation in future clinical trials.

\section{DATA AVAILABILITY STATEMENT}

The raw data supporting the conclusions of this article will be made available by the authors, without undue reservation.

\section{ETHICS STATEMENT}

The studies involving human participants were reviewed and approved by Innovation and Research Direction (reference 2020PI080), and by the Research Ethical Committee (Saisine 263) of CHRU-Nancy. The patients/participants provided their written informed consent to participate in this study.

\section{AUTHOR CONTRIBUTIONS}

DP, M-RL, and MCB contributed on conceptualization and study design. MC, HM, CD, LP, M-RL, and MCB performed experiments, provided samples, and generated data. DP, ClD, and M-RL analyzed data. DP and MCB wrote the original draft. $\mathrm{DP}, \mathrm{ClD}, \mathrm{M}-\mathrm{RL}$, and MCB reviewed and edited the manuscript. All authors contributed to the article and approved the submitted version.

\section{ACKNOWLEDGMENTS}

The authors thank the helpful comments of Professors Philippe Saas (Besançon, France) and Marie-Christine Béné (Nantes, France) as well as the support of Drs. Patricia Franck and Véronique Latger-Cannard from Pôle Laboratoires of CHRU- 
Nancy. The authors also thank the paramedical and medical team taking care of COVID-19 patients in the Surgical Intensive Care Unit of CHRU-Nancy at Brabois Hospital. This manuscript has been released as a pre-print at medRxiv: https://medrxiv.org/ cgi/content/short/2020.06.16.20130914v1 (43).

\section{REFERENCES}

1. Zhou F, Yu T, Du R, Fan G, Liu Y, Liu Z, et al. Clinical course and risk factors for mortality of adult inpatients with COVID-19 in Wuhan, China: a retrospective cohort study. Lancet (2020) 395(10229):1054-62. doi: 10.1016/ S0140-6736(20)30566-3

2. Phua J, Weng L, Ling L, Egi M, Lim CM, Divatia JV, et al. Intensive care management of coronavirus disease 2019 (COVID-19): challenges and recommendations. Lancet Respir Med (2020) 8(5):506-17. doi: 10.1016/ S2213-2600(20)30161-2

3. Li S, Jiang L, Li X, Lin F, Wang Y, Li B, et al. Clinical and pathological investigation of severe COVID-19 patients. JCI Insight (2020) 5(12):e138070. doi: $10.1172 /$ jci.insight. 138070

4. Chen G, Wu D, Guo W, Cao Y, Huang D, Wang H, et al. Clinical and immunological features of severe and moderate coronavirus disease 2019. J Clin Invest (2020) 130(5):2620-9. doi: 10.1172/JCI137244

5. Giamarellos-Bourboulis EJ, Netea MG, Rovina N, Akinosoglou K, Antoniadou A, Antonakos N, et al. Complex Immune Dysregulation in COVID-19 Patients with Severe Respiratory Failure. Cell Host Microbe (2020) 27(6):992-1000 e3. doi: 10.1016/j.chom.2020.04.009

6. Lukaszewicz AC, Grienay M, Resche-Rigon M, Pirracchio R, Faivre V, Boval B, et al. Monocytic HLA-DR expression in intensive care patients: interest for prognosis and secondary infection prediction. Crit Care Med (2009) 37 (10):2746-52. doi: 10.1097/CCM.0b013e3181ab858a

7. Vardhana SA, Wolchok JD. The many faces of the anti-COVID immune response. J Exp Med (2020) 217(6):e20200678. doi: 10.1084/jem.20200678

8. Ingraham NE, Lotfi-Emran S, Thielen BK, Techar K, Morris RS, Holtan SG, et al. Immunomodulation in COVID-19. Lancet Respir Med (2020) 8(6):544-46. doi: 10.1016/S2213-2600(20)30226-5

9. Payen D. Immunity check should be performed for all patients with septic shock? No. Intensive Care Med (2020) 46(3):506-9. doi: 10.1007/s00134-01905923-4

10. Wong KL, Yeap WH, Tai JJ, Ong SM, Dang TM, Wong SC. The three human monocyte subsets: implications for health and disease. Immunol Res (2012) 53 (1-3):41-57. doi: 10.1007/s12026-012-8297-3

11. Payen D, Faivre V, Miatello J, Leentjens J, Brumpt C, Tissieres P, et al. Multicentric experience with interferon gamma therapy in sepsis induced immunosuppression. A case series. BMC Infect Dis (2019) 19(1):931. doi: 10.1186/s12879-019-4526-x

12. Sampath P, Moideen K, Ranganathan UD, Bethunaickan R. Monocyte Subsets: Phenotypes and Function in Tuberculosis Infection. Front Immunol (2018) 9:1726. doi: 10.3389/fimmu.2018.01726

13. Ziegler-Heitbrock L. Blood Monocytes and Their Subsets: Established Features and Open Questions. Front Immunol (2015) 6:423. doi: 10.3389/ fimmu.2015.00423

14. Gouel-Cheron A, Allaouchiche B, Floccard B, Rimmele T, Monneret G. Early daily mHLA-DR monitoring predicts forthcoming sepsis in severe trauma patients. Intensive Care Med (2015) 41(12):2229-30. doi: 10.1007/s00134-015-4045-1

15. Seddiki N, Santner-Nanan B, Martinson J, Zaunders J, Sasson S, Landay A, et al. Expression of interleukin (IL)-2 and IL-7 receptors discriminates between human regulatory and activated T cells. J Exp Med (2006) 203 (7):1693-700. doi: 10.1084/jem.20060468

16. Liu W, Putnam AL, Xu-Yu Z, Szot GL, Lee MR, Zhu S, et al. CD127 expression inversely correlates with FoxP3 and suppressive function of human CD4+ T reg cells. J Exp Med (2006) 203(7):1701-11. doi: 10.1084/jem.20060772

17. Seder RA, Darrah PA, Roederer M. T-cell quality in memory and protection: implications for vaccine design. Nat Rev Immunol (2008) 8(4):247-58. doi: $10.1038 /$ nri2274

18. Boyd A, Almeida JR, Darrah PA, Sauce D, Seder RA, Appay V, et al. Pathogen-Specific T Cell Polyfunctionality Is a Correlate of T Cell Efficacy

\section{SUPPLEMENTARY MATERIAL}

The Supplementary Material for this article can be found online at: https://www.frontiersin.org/articles/10.3389/fimmu.2020. 580250/full\#supplementary-material

and Immune Protection. PLoS One (2015) 10(6):e0128714. doi: 10.1371/ journal.pone.0128714

19. Lamoreaux L, Koup RA, Roederer M. OMIP-009: Characterization of antigenspecific human T-cells. Cytometry A (2012) 81(5):362-3. doi: 10.1002/ cyto.a. 22042

20. Larsen M, Sauce D, Arnaud L, Fastenackels S, Appay V, Gorochov G. Evaluating cellular polyfunctionality with a novel polyfunctionality index. PLoS One (2012) 7(7):e42403. doi: 10.1371/journal.pone.0042403

21. Calandra T, Cohen JI. C. U. C. C. International Sepsis Forum Definition of Infection in the. The international sepsis forum consensus conference on definitions of infection in the intensive care unit. Crit Care Med (2005) 33 (7):1538-48. doi: 10.1097/01.ccm.0000168253.91200.83

22. Biller K, Fae P, Germann R, Drexel H, Walli AK, Fraunberger P. Cholesterol rather than procalcitonin or $\mathrm{C}$-reactive protein predicts mortality in patients with infection. Shock (2014) 42(2):129-32. doi: 10.1097/SHK.0000000000000187

23. Ozanska A, Szymczak D, Rybka J. Pattern of human monocyte subpopulations in health and disease. Scand J Immunol (2020) 92(1): e12883. doi: $10.1111 /$ sji.12883

24. Chen ATC, Coura-Filho GB, Rehder MHH. Clinical Characteristics of Covid19 in China. N Engl J Med (2020) 382(19):1860. doi: 10.1056/NEJMc2005203

25. Weiskopf D, Schmitz KS, Raadsen MP, Grifoni A, Okba NMA, Endeman H, et al. Phenotype and kinetics of SARS-CoV-2-specific T cells in COVID-19 patients with acute respiratory distress syndrome. Sci Immunol (2020) 5(48): eabd2071. doi: 10.1126/sciimmunol.abd2071

26. Guan WJ, Ni ZY, Hu Y, Liang WH, Ou CQ, He JX, et al. Clinical Characteristics of Coronavirus Disease 2019 in China. N Engl J Med (2020) 382(18):1708-20. doi: 10.1056/NEJMoa2002032

27. Xu Z, Shi L, Wang Y, Zhang J, Huang L, Zhang C, et al. Pathological findings of COVID-19 associated with acute respiratory distress syndrome. Lancet Respir Med (2020) 8(4):420-2. doi: 10.1016/S2213-2600(20)30076-X

28. Merad M, Martin JC. Pathological inflammation in patients with COVID-19: a key role for monocytes and macrophages. Nat Rev Immunol (2020) 20 (6):355-62. doi: 10.1038/s41577-020-0331-4

29. Tay MZ, Poh CM, Renia L, MacAry PA, Ng LFP. The trinity of COVID-19: immunity, inflammation and intervention. Nat Rev Immunol (2020) 20 (6):363-74. doi: 10.1038/s41577-020-0311-8

30. Zhang D, Guo R, Lei L, Liu H, Wang Y, Wang Y, et al. COVID-19 infection induces readily detectable morphological and inflammation-related phenotypic changes in peripheral blood monocytes, the severity of which correlate with patient outcome. medRxiv (2020). doi: 10.1101/2020.03. 24.20042655

31. Wang F, Hou H, Luo Y, Tang G, Wu S, Huang M, et al. The laboratory tests and host immunity of COVID-19 patients with different severity of illness. JCI Insight (2020) 5(10):e137799. doi: 10.1172/jci.insight.137799

32. Zeng Q, Li Y-Z, Huang G, Wu W, Dong S-Y, Xu Y. Mortality of COVID-19 is Associated with Cellular Immune Function Compared to Immune Function in Chinese Han Population. medRxiv (2020). doi: 10.1101/ 2020.03.08.20031229

33. Cox MA, Kahan SM, Zajac AJ. Anti-viral CD8 T cells and the cytokines that they love. Virology (2013) 435(1):157-69. doi: 10.1016/j.virol.2012.09.012

34. Swain SL, McKinstry KK, Strutt TM. Expanding roles for CD4(+) T cells in immunity to viruses. Nat Rev Immunol (2012) 12(2):136-48. doi: 10.1038/ nri3152

35. Burel JG, Apte SH, Groves PL, McCarthy JS, Doolan DL. Polyfunctional and IFNgamma monofunctional human $\mathrm{CD} 4(+) \mathrm{T}$ cell populations are molecularly distinct. JCI Insight (2017) 2(3):e87499. doi: 10.1172/jci.insight.87499

36. Ni L, Ye F, Cheng ML, Feng Y, Deng YQ, Zhao H, et al. Detection of SARSCoV-2-Specific Humoral and Cellular Immunity in COVID-19 Convalescent Individuals. Immunity (2020) 52(6):971-7 e3. doi: 10.1016/j.immuni. 2020.04 .023 
37. Braun J, Loyal L, Frentsch M, Wendisch D, Georg P, Kurth F, et al. Presence of SARS-CoV-2 reactive T cells in COVID-19 patients and healthy donors. medRxiv (2020). doi: 10.1101/2020.04.17.20061440

38. Grifoni A, Weiskopf D, Ramirez SII, Mateus J, Dan JM, Rydyznski Moderbacher $\mathrm{C}$, et al. Targets of $\mathrm{T}$ cell responses to SARS-CoV-2 coronavirus in humans with COVID-19 disease and unexposed individuals. Cell (2020) 181(7):1489-501 e15. doi: 10.1016/j.cell.2020.05.015

39. Oh HL, Chia A, Chang CX, Leong HN, Ling KL, Grotenbreg GM, et al. Engineering $\mathrm{T}$ cells specific for a dominant severe acute respiratory syndrome coronavirus $\mathrm{CD} 8$ T cell epitope. J Virol (2011) 85(20):10464-71. doi: 10.1128/JVI.05039-11

40. Diao B, Wang C, Tan Y, Chen X, Liu Y, Ning L, et al. Reduction and Functional Exhaustion of T Cells in Patients With Coronavirus Disease 2019 (COVID-19). Front Immunol (2020) 11:827. doi: 10.3389/fimmu.2020.00827

41. Wherry EJ, Kurachi M. Molecular and cellular insights into T cell exhaustion. Nat Rev Immunol (2015) 15(8):486-99. doi: 10.1038/nri3862

42. Dekeyser M, Ladriere M, Audonnet S, Frimat L, De Carvalho Bittencourt M. An Early Immediate Early Protein IE-1-Specific T-Cell Polyfunctionality Is Associated
With a Better Control of Cytomegalovirus Reactivation in Kidney Transplantation. Kidney Int Rep (2017) 2(3):486-92. doi: 10.1016/j.ekir.2017.02.016

43. Payen D, Cravat M, Maadadi H, Didelot C, Prosic L, Dupuis C, et al. A longitudinal study of immune cells in severe COVID-19 patients. medRxiv (2020) 2020.06.16.20130914. doi: 10.1101/2020.06.16.20130914

Conflict of Interest: The authors declare that the research was conducted in the absence of any commercial or financial relationships that could be construed as a potential conflict of interest.

Copyright $\odot 2020$ Payen, Cravat, Maadadi, Didelot, Prosic, Dupuis, Losser and De Carvalho Bittencourt. This is an open-access article distributed under the terms of the Creative Commons Attribution License (CC BY). The use, distribution or reproduction in other forums is permitted, provided the original author(s) and the copyright owner(s) are credited and that the original publication in this journal is cited, in accordance with accepted academic practice. No use, distribution or reproduction is permitted which does not comply with these terms. 